\title{
Effects of Indole-3-butyric Acid on the Rooting Ability of Semi-hardwood Bougainvillea sp. Cuttings
}

\author{
Marzieh Babashpour Asl ${ }^{1}$, Somayeh Shakueefar ${ }^{1} \&$ Vida Valipour ${ }^{1}$ \\ ${ }^{1}$ Department of Horticultural Science, Islamic Azad University of Maragheh Branch, East Azerbaijan, Iran \\ Correspondence: Marzieh Babashpour Asl, Department of Horticultural Science, Islamic Azad University of \\ Maragheh Branch, PO box 345 Maragheh, East Azerbaijan, Iran. Tel: 98-91-4301-5052. E-mail: \\ babashpour@iau-maragheh.ac.ir
}

Received: March 16, 2011

doi:10.5539/mas.v6n5p121

\author{
Accepted: April 25, $2012 \quad$ Online Published: May 1, 2012 \\ URL: http://dx.doi.org/10.5539/mas.v6n5p121
}

\begin{abstract}
The experiment was carried out to investigate the effect of different concentration of Indole-3-butyric acid (IBA) on the rooting ability of semi-hardwood Bougainvillea flower. The treatments were control (without IBA), 2000, 3000 and $4000 \mathrm{ppm}$ IBA. The cuttings were treated with IBA solution for 7 seconds and immediately transferred to the rooting medium. Perlite was used as a rooting substrate. Treatment was evaluated in a completely randomized design (CRD) with 3 replications. According to the obtained results, there was no significant difference between IBA treatment and control on rooting percentage. The best effect of different levels of IBA on the number of root ( 8.67 roots per plant) was obtained at $2000 \mathrm{ppm}$ IBA. The highest root length $(151.42 \mathrm{~mm})$ was observed at control and there was no significant difference between control and 2000, $4000 \mathrm{ppm}$ IBA. It can be concluded that using perlite as a rooting substrate without using IBA (control) affected rooting ability in bougainvillea flower.
\end{abstract}

Keywords: Bogainvillea, indole-3-butyric acid, rooting, IBA

\section{Introduction}

The genus Bougainvillea, in the Nyctaginaceae (Four-o'clock) family of plants, has 14 species, with three that are horticulturally important. Bougainvillea is used to decorate fences and arbors with explosions of color in the house corridor, office and play ground. A bougainvillea tree can make guarding the entry or framing a window. Bougainvillea is a great vine for large containers to decorate hot patios and plazas. Bougainvillea is also used to create beautiful flowering bonsai specimens (Sharif Hossain et al., 2007). Bougainvillea is native to South America. The name comes from Louis Antoine de Bougainville, a French navigator and military commander who was the first European to take note of the plant, in Brazil, in 1768 (Kobayashi et al., 2007). Softwood terminals, maturing green wood, and matured intermediate wood stem pieces can be used for propagation of Bougainvillea flower (Hacket et al., 1972). Softwood terminals of easy-to-root cultivars do not require a rooting hormone. With more mature wood, a rooting hormone such as IBA (3-indolebutryic acid) at 2000-6000 ppm is commonly used (Kobayashi et al., 2007). Higher concentrations may be needed with more difficult-to-root cultivars (Gilman, 1999).

Moalemi and Chehrazi (2005) reported that high percentage of rooting were for leafy cutting. In that study, the highest number of roots was obtained in leafless cutting ( 9.23 roots per plant) at $2000 \mathrm{mg} \mathrm{L}^{-1}$ IBA. The best effect of different levels of auxin on root length $(5.79 \mathrm{~cm})$ was obtained leafless cuttings at $1000 \mathrm{mg} \mathrm{L}^{-1} \mathrm{NAA}$. In other study, under the influence of $0.2-0.4 \%$ of IBA the cutting rooted in $66-88 \%$. In control treatment, without auxins, the cuttings rooted $22.5-93 \%$ but their root system was very poorly developed. In the former report, rooting medium has not been said, but in the latter one, rooting medium was sand (Czekalski, 1989)

The purpose of this study is to improve rooting ability with more difficult-to-root cultivars of Bongainvillea flower.

\section{Materials and Methods}

This study was carried out at Department of Horticultural Science, Islamic Azad University of Maragheh Branch, Maragheh, Iran in 2009.

Treatment was evaluated in a completely randomized design (CRD) with 3 replications. Each replication consisted of 10 cuttings. Semi-hardwood Bougainvillea cuttings used in this study were taken in December. 
Shoots originating from branches with flower were not taken as cutting since the presence of flower on cutting prevents rooting (Hartman et al., 1990).

Perlite was used as a rooting substrate. Auxins are widely used for promoting rooting of hardwood cuttings (Leaky et al., 1982; Smith, 1986; Hartman et al., 1990), so IBA was used as a rooting hormone. The formulations were prepared by dissolving the pure compound in $95 \%$ ethanol and adding distillated water. Cutting prepared after discarding the non-hardened upper parts bearing 4-5 buds. In order to reduce the transpiration, the leaf area was reduced $50-80 \%$. The basal end of cuttings were dipped briefly in a fungicide solution $(0.1 \% \mathrm{w} / \mathrm{v}$ Captain) prior to treatment with IBA solutions.

During the rooting period, the mean temperature was registered as $20^{\circ} \mathrm{C}$ and the mean moisture was registered at $45 \%$ in the greenhouse.

To evaluate the rooting of the cutting, a 22-weeks period was taken as a basis. Czekalski (1989) indicated in his study that the rooting process lasted 10-22 weeks. After 22 weeks, root counting and measurements were performed after removing cuttings from the rooting environment. In the measurements, rooting percentage, mean root number and the mean of the longest 4 roots $(\mathrm{mm})$ were recorded. The collected data were evaluated with the statistical program SAS and the means were compared using Duncan's multiple rang tests.

\section{Results}

The results of this experiment are summarized in Table 1. According to the results, there was no significant difference between IBA treatment and control on rooting percentage. There was significant difference between IBA treatment and control on the number of main roots per cutting. The best effect of different levels of IBA on the number of main roots per cutting (8.67 roots per cutting) was obtained at $2000 \mathrm{ppm}$ IBA.

Table 1. Effect of different concentration of IBA on rooting percentage, number of main root per cutting and root length of bougainvillea flower

\begin{tabular}{cccc}
\hline Treatments & $\begin{array}{l}\text { Rooting } \\
\text { percentage }\end{array}$ & $\begin{array}{l}\text { Number of main root } \\
\text { per cutting }\end{array}$ & Root length (mm) \\
\cline { 1 - 3 } IBA (ppm) & & $6.31^{\mathrm{ab}}$ & $151.42^{\mathrm{a}}$ \\
\cline { 1 - 2 } Control & $66.67^{\mathrm{a}}$ & $8.67^{\mathrm{b}}$ & $113.00^{\mathrm{a}}$ \\
2000 & $76.19^{\mathrm{a}}$ & $4.72^{\mathrm{b}}$ & $28.69^{\mathrm{b}}$ \\
3000 & $66.67^{\mathrm{a}}$ & $8.94^{\mathrm{ab}}$ & $107.58^{\mathrm{a}}$ \\
4000 & $42.86^{\mathrm{a}}$ & &
\end{tabular}

Means in each column with same letters are not significantly different at $5 \%$ level

Also, IBA affected significantly the root length. The highest root length $(151.42 \mathrm{~mm})$ was observed at control (without IBA), and there was no significant difference between control and 2000, $4000 \mathrm{ppm}$.

\section{Discussion}

Although auxins have been successfully used to promote rooting of hardwood and semi-hardwood cuttings, (Halle \& Hanif-Kamil, 1981; Leaky et al., 1982; Smith, 1983a, 1986b) rooting of easy-to-root cultivars of Bougainvillea cuttings has been previously reported (Kobayashi et al., 2007). Even in these cultivars with more mature wood, a rooting hormone such as IBA is commonly used. Cuttings used for this experiment were taken from semi-hardwood branches of Juvenile stockplants. Juvenility may be an important factor in the rooting potential in different plants (Momose, 1978, Halle \& Hanif-kamil, 1981; Smith, 1983a, 1986b). Juvenile tissues of woody plants tend to have higher levels of endogenous auxin and are less differentiated and therefore more prone to dedifferentiated (Hackett, 1985, Hartman et al., 1990). Haissig (1974) postulated that phenols in juvenile tissues of certain plants tend to be higher than their mature forms. Also, cuttings were prepared including the apical meristems of stock plants, the region where auxins are synthesized in plants (Kramer \& Kozlowski, 1979). Furthermore, rooting substrate used for this experiment was perlite. In previous studies with bougainvillea flower, has not been used perlite as a medium. Perhaps perlite has affected rooting ability. Perlite has many characteristics similar to sand and is commonly used as a low-weight replacement for sand (Dole \& 
Wilkins, 1999). Perlite, like sand has low water retention but excellent aeration. It is essential that the different media be compared for determining the best medium for Bougainvillea flower.

\section{References}

Czekalski, M. L. (1989). The influence of Auxins on the rooting of cuttings of Bougainvillea glabra Choisy. International Symposium on Growth Regulators on Ornamental Horticulture.

Dole, J. M., \& Wilkins, H. F. (1999). Floriculture. Principles and practices. Prentice-Hall International Edition. New Jersey, 328.

Gilman, E. F. (1999). Bougainvillea spp. Cooperative Extension Service, University of Florida, Fact Sheet FPS-70.

Hacket, W. P. (1985). Juvenility, maturation and rejuvenation in woody plants. Horticultural Reviews, 7 , 109-155.

Hackett, W. P., Sachs, R. M., \& Debie, J. (1972). Growing Bougainvillea as a flowering pot plant. California Agriculture, 26(8), 12-13.

Halle, F., \& Hanif-Kamil, L. (1981). Vegetative propagation of dipterocarps by stem cuttings and air layerig. Malaysia Forester, 44(2\&3), 314-318.

Haissig, B. E. (1974). Influence of auxins and auxin synergists on adventitious root primordium initiation and development. New Zealand Journal of Forest Science, 4, 311-323.

Hartman, H. T., Kester, D. E., \& Davies, F. T. (1990). Plant Propagation. Principles and Practices. Fifth edition. Prentice -Hall International Edition. New Jersey, 645.

Kobayashi, K. D., McConnel, J., \& Griffis, J. (2007). Bougainvillea. Cooperative Extension Service. College of tropical Agriculture and Human Resources. University of Hawai'i at Monoa, OF-38.

Kramer, P. J., \& Kozlowski, T. T. (1979). Physiology of Woody Plants. London: Academic Press, p. 811.

Leaky, R. R. B., Charman, V. R., \& Longman, K. A. (1982). Physiological studies for tree improvement and conservation. Factors affecting root initiation in cuttings of Triplochiton scleroxylon K. Schum. Forest Ecology and management, 4, 53-66. http://dx.doi.org/10.1016/0378-1127(82)90028-7

Moalemi, N., \& Chehrazi, M. (2005). The effect of different Auxins on Rooting of leafy and leafless cuttings of Bougainvillea spectabilis in plastic tunnel. The science journal of Agriculture, 27(2), 127-138

Momose, Y. (1978). Vegetative propagation of Malaysian trees. Malaysian Forester, 41(3), 219-223.

Sharif Hossain, A. B. M., Boyce, A. N., \& Osman, N. (2007). Postharvest quality, Vase life and photosynthetic yield of Bougainvillea flower by applying ethanol. Australian Journal of Basic and Applied Sciences, 1(4), 733-740.

Smiths, W. T. M. (1983). Vegetative propagation of Shorea of. obtusa and Agathis dammara by means of leaf-cuttings and stem-cuttings. Malaysian Forester, 46(2), 175-185.

Smiths, W. T. M. (1986). Vegetative propagation and possibilities for its use with Dipterocarpaceae. In Wirakusumah, S (ed.) Diskusi Tebatas Beberapa Aspek Pembangunan Hutan. Menelusuri Cara-Cara Inovatif Reboisasi di Indonesia I. Jakarta. INHUTANI I, 8. 